URSZULA WolaK

\title{
Po co Czesi jadą na wakacje czyli Wycieczkowicze w reżyserii Jiříego Vejděleka według powieści Michala Viewegha
}

Komedia Wycieczkowicze w reżyserii Jiř́iego Vejděleka z 2006 r. zabiera widzów w podróż z Pragi do włoskiego kurortu, gdzie mają spełnić się najskrytsze marzenia uczestników jednej z wycieczek. Na zbiórkę, tuż przed odjazdem klimatyzowanego autokaru, stawiają się m.in.: para gejów, małżeństwo z dojrzałą, trzydziestoparoletnią córką, para z dwójką małych dzieci, dwie studentki, gwiazdor muzyki popularnej, dwie ekscentryczne przyjaciółki w podeszłym wieku i nieprzyciągający niczyjej uwagi mężczyzna - typ skrytego naukowca. Opiekę nad wycieczkowiczami sprawuje pilotka - blondwłosa, długonoga piękność o wdzięcznym imieniu Pamela.

Każdy z pasażerów wsiada do autokaru z własnymi oczekiwaniami. Jedni marzą o płomiennym romansie, inni chcą po prostu wypocząć, wylegując się na nagrzanym od słońca piasku, a niektórzy udają się do Włoch w poszukiwaniu wspomnień o utraconej przed laty miłości. Możemy spodziewać się jednego. Podróż do słonecznej Italii z pewnością odmieni życie niejednego wycieczkowicza.

Bohaterowie tworzą $\mathrm{w}$ filmie Vejděleka interesującą mozaikę różnych osobowości - „zwykłych" Czechów, ukazanych w nieco krzywym zwierciadle. Ostrze humoru skierowane jest tu przeciwko ludzkim przywarom, błędom i zaściankowości. Ich zachowanie odzwierciedla stereotypowe myślenie o kobietach i mężczyznach, starszych i młodszych oraz małżeństwach z długoletnim stażem. Burzy jednak stereotypowe myślenia o gejach. Błaha z pozoru opowieść porusza także aktualne problemy społeczno-polityczne dotyczące na przykład adopcji dzieci przez związki homoseksualne i podejścia Czechów do homoseksualizmu. 


\section{Król czeskiej literatury popularnej}

Autor powieści, na podstawie której Vejdĕlek nakręcił film jest jednym z najpoczytniejszych czeskich pisarzy, nie tylko w kraju, ale i za granicą. Stwierdzenie to znajduje potwierdzenie w liczbach. Michal Viewegh ma na swoim koncie ponad milion sprzedanych egzemplarzy książek w samych Czechach. Jego powieści przetłumaczono na 21 języków, siedem zostało zekranizowanych (m.in. Wychowanie dziewczat w Czechach i Mężczyzna idealny), a dwie zaadaptowano w teatrze (m.in. Wycieczkowicze) $)^{1}$. Popularność Viewegha odbija się także $\mathrm{w}$ dowcipnych słowach Mariusza Szczygła, znawcy czeskiej kultury i literatury: „Całe Czechy czytają Viewegha. Nawet jeśli kilkoro Czechów nie czyta, nie zmienia to jednak pozycji króla czeskiej literatury. Nic się nie da z tym faktem zrobić. Wypada to tylko uszanować i zaakceptować. Nie można przecież walczyć z całym narodem”².

Michal Viewegh urodził się w 1962 r. w Pradze. Tam też ukończył filologię czeską na Uniwersytecie Karola. Po odbyciu służby wojskowej zaczął pracować jako nauczyciel w szkole podstawowej, a następnie pełnił funkcję redaktora $\mathrm{w}$ jednym $\mathrm{z}$ czeskich wydawnictw. Pisarstwem zajmuje się zawodowo od $1995 \mathrm{r}^{3}$

\section{Wycieczkowicze w Polsce}

W Polsce do najbardziej znanych powieści Michala Viewegha należą m.in.: Wychowanie dziewczat w Czechach (1994), Aniołowie dnia powszedniego (2007) i Wycieczkowicze (2008). Prostą, humorystyczną opowieść o grupie Czechów, którzy spędzają wymarzone wakacje we włoskim kurorcie, najlepiej opisują słowa samego Viewegha: „Pozornie zwyczajne, pospolite, ludzkie historie mogą być wielkie i ważne oraz zdecydowanie bardziej ciekawe i wymagające umiejętności pisarskich niż wielkie tematy, jak śmierć, choroby, tragedie. Trzeba wierzyć w siłę historii, którą się opowiada, wtedy niepotrzebne będą kwieciste zwroty i językowe eksperymenty" ${ }^{\prime \prime 4}$.

1 Dane te zaczerpnęłam $\mathrm{z}$ oficjalnej strony internetowej Michala Viewegha: www.viewegh.cz (dostęp: 23.07.2012).

2 Te słowa Mariusza Szczygła promują Wychowanie dziewcząt w Czechach autorstwa Michala Viewegha. Książka została wydana w Polsce nakładem wydawnictwa Agora w styczniu 2012 r.

3 www.viewegh.cz (dostęp: 23.07.2012).

4 Tamże. 
Argumentacja Viewegha zdaje się jednak nie trafiać do polskich krytyków, którzy nie pochylają się zbyt nisko nad jego twórczością, uważając ją po prostu za banalną. Czescy recenzenci zarzucają natomiast Vieweghowi powierzchowność. Autor podchodzi jednak do ich słów z dystansem, a w Wycieczkowiczach umieścił nawet fragmenty niektórych kąśliwych recenzji swoich książek. Czytamy na przykład: Ten wstawiony, krótki tekst jako jedyny z całej powieści sugeruje, dokąd autor mógłby zajść, gdyby w końcu pozbyt się szczeniackiego zblazowania i pozy intelektualnego playboya ${ }^{5}$.

Zdaniem Viewegha czeska krytyka bagatelizuje siłę humoru tkwiąca w jego powieściach: „Od razu przypisuje się mu estradowość, powierzchowność, zupełnie jakby humor czy ironia były nierozerwalnie połączone $\mathrm{z}$ powierzchownością" ${ }^{\prime \prime}$. Ironia stanowi też w Wycieczkowiczach podstawowy pisarski środek wyrazu. Viewegh posługuje się nią świadomie, opisując zarówno wady, jak i zalety bohaterów swojej powieści. Robi to jednocześnie z zauważalną czułością. W ich zachowaniach odbijają się bowiem wątki z prywatnego życia autora. W wywiadzie udzielonym Mirosławowi Śmigielskiemu powiedział, że za pomocą Jolany przedstawił swoje relacje z rodzicami i że jest obecny w książce także pod postacią Maxa ${ }^{7}$.

Autor opisuje też czeskich uczestników wycieczki w konwencji absurdu, który obok ironii jest źródłem humoru. Absurdalny charakter ma na przykład romans Jolany z brutalnym Olegiem. Mimo że wulgarny Ukrainiec zachowuje się w łóżku jak nieokrzesany samiec i traktuje kobietę jak przedmiot, śmiejemy się, kiedy Jolana, w momencie odbywania z nim stosunku płciowego, myśli: Jeśli przeżyć chcesz harówkę, kup se ruska wyścigówkę $e^{8}$.

\section{Literatura a film}

Reżyser, adaptując Wycieczkowiczów Viewegha, zrezygnował z kilku postaci, które odegrały kluczowe role $\mathrm{w}$ jego popularnej powieści, a jednej bohaterce zmienił imię z Lidki na Jituš. Linearna narracja prowadzona w filmie pozostała jednak wierna literze powieści. Pominięcie przez twórców fragmentów książki ma swoje znaczące uzasadnienie.

\footnotetext{
Michal Viewegh, Wycieczkowicze, tłum. Jacek Illg, Prószyński i S-ka, Warszawa 2008, s. 76.

6 Mirosław Śmigielski, Pisarz o wielkiej skali głosu, wywiad z Michalem Vieweghiem opublikowany na łamach czasopisma „Pan Slawista” 2009, nr 2. Tekst znajduje się także na stronie internetowej: www.novinka.pl (dostęp: 29.07.2012).

7 Tamże.

8 Michal Viewegh, dz. cyt., s. 326.
} 
Pewne wątki i niektórzy bohaterowie nie pasowali do obrazu czeskości, upowszechnianego $\mathrm{w}$ kinie przez lata, m.in. w filmach takich jak Pociagi pod specjalnym nadzorem (1966) Jiříego Menzla, Pali się moja panno (1967) Miloša Formana czy Guzikowcy (1997) i Opowieści o zwyczajnym szaleństwie (2005) Petra Zelenki. Wycieczkowicze Vejděleka kontynuują tradycję przedstawiania w kinie Czechów jako dobrodusznych i poczciwych bohaterów, których wszystkie wady ukazane zostały z pełnym zrozumieniem i życzliwością.

W filmowej adaptacji powieści nie zobaczymy więc zadufanego w sobie posła Hynka i jego żony Zuzanny ${ }^{9}$. Czeski twórca pominął też wątek tajemniczej pary, pana Petrescu i jego towarzyszki oraz ukraińskiego emigranta, Olega, przedstawionego $\mathrm{w}$ powieści w negatywnym świetle jako zaściankowego brutala ${ }^{10}$. Max - $\mathrm{w}$ powieści pisarz ${ }^{11}$ - staje się $\mathrm{w}$ filmie popularnym piosenkarzem. Autobiograficzne wątki, obecne w utworze Viewegha, schodzą więc w filmie na dalszy plan. Vejdělek postanowił też rozbudować postać Šarloty, nobliwej staruszki, która nie potrafi pogodzić się ze śmiercią swojego męża ${ }^{12}$.

\section{Karel i Karel, czyli czeska złośliwość}

Panami pojazdu wiozącego wycieczkowiczów do Włoch są dwaj kierowcy: Karel i Karel. To oni sprawują najwyższą władzę w autokarze. Czuwają nad bezpieczeństwem pasażerów i przestrzeganiem panującego na pokładzie regulaminu. Wycieczkowicze dowiadują się, że mają prawo poprosić o postój autokaru w każdej chwili. Na życzenie otrzymają też ciepłe i zimne napoje. Oczkiem w głowie czeskich kierowców okazują się brązowe kubki do ich spożywania. Każdy z wycieczkowiczów winien je natychmiast zwrócić po wypiciu gorącej kawy czy herbaty. Podróżni grzecznie przytakują, że będą przestrzegać ostatniego punktu regulaminu. Na pierwszym postoju okazuje się jednak, że kilku podróżnych nie zwróciło brązowych kubków, a kierowcy stracili nadzieję, że kiedykolwiek je odzyskają ${ }^{13}$.

Stosunek bohaterów do plastikowych naczyń to przykład czeskiej złośliwości, działania na przekór obowiązującym zasadom. Jedni, jak na

\footnotetext{
9 Tamże, s. 20.

10 Tamże, s. 28, 303.

11 Tamże, s. 23.

12 Tamże, s. 277.

13 Tamże, s. 33, 39-40.
} 
przykład Ignác i Oskar, przywłaszczają sobie kubki, by zakpić z władczych kierowców - Karela i Karela, inni natomiast, jak zaściankowi Jarda i Jituš, uznają, że skoro zapłacili za wycieczkę, mogą przywłaszczyć sobie plastikowe pojemniki.

Vejdělek wiedział, że nie urazi Czechów, przedstawiając ich jako małych oszustów. Kto bowiem nie skorzystałby z nadarzającej się okazji i nie przywłaszczyłby sobie darmowych kubeczków? Zawsze mogą się na coś przydać i Karel z Karelem muszą się z tym pogodzić lub znaleźć inny sposób, by zabezpieczyć się przed kradzieżą w przyszłości.

\section{Ignác i Oskar, czyli normalni geje}

Para gejów tworzy w filmie Vejděleka, jak i w powieści Viewegha, związek idealny. Portrety Ignáca i Oskara są dalekie od stereotypowych wyobrażeń o gejach, powszechnie istniejących w społecznej świadomości. Ignác wcale nie jest zniewieściały, a Oskar nie uosabia cech mężczyzny - macho. To zwyczajni, normalni faceci, którzy nie kryją się z własnymi uczuciami $^{14}$. Na oczach wycieczkowiczów całują się namiętnie, sygnalizując tym samym swoją orientację i wywołując zróżnicowane reakcje pozostałych pasażerów - od zrozumienia po obawy. Znaczący jest jednak fakt, że nikt nie jest zdziwiony ich zachowaniem. Bo Czesi - jak zdaje się mówić Vejdělek - już dawno zaakceptowali zachowania seksualne odmienne od normy hetero. Pamela, seksowna pilotka wycieczki, na wieść o łączącej mężczyzn miłości natychmiast wyraziła swój entuzjazm ${ }^{15}$.

Niektórzy jednak, tak jak Jarda i Jituš, wciąż traktują gejów jak niebezpiecznych dla otoczenia dewiantów. Małżeństwo z dwójką dzieci nie wie jednak, że ich syn Jakub żyje w przekonaniu, że sam jest gejem. Chłopiec cierpi od lat na wstydliwą przypadłość. W szkole oddaje mocz tylko w samotności i nigdy nie korzysta z pisuarów. Przypadkowo dowiaduje się, że lęk przed publicznym wystawieniem penisa oznacza, że jest homoseksualistą. Ta wiadomość go jednak nie załamuje. We Włoszech próbuje zbliżyć się do Oskara, by dowiedzieć się jak najwięcej o zachowaniach gejów. Za wszelką cenę pragnie też zdobyć maść, którą mężczyźni stosują w czasie odbywania stosunku płciowego. Kradnie pożądany specyfik Oskarowi. Dzieciak nie wie jednak, że wszedł w posiadanie maści tygrysiej o silnie piekących właściwościach.

14 Tamże, s. 167-170, 227-228.

15 Tamże, s. 170. 
Ignác i Oskar z rozczuleniem patrzą na Jakuba i jego siostrę. Bawią się z dzieciakami na plaży i okazują im swoje zainteresowanie. Sami bowiem pragną mieć dzieci. Prawo wciąż jednak stoi na przeszkodzie w realizacji ich celu. W powieści za taki stan rzeczy Ignác oskarża papieża. W rozmowie z Oskarem powiedział dokładnie, że chce na własne oczy zobaczyć człowieka, który zabrania parom homoseksualistów adopcji dzieci ${ }^{16}$. W filmie nie padają już tak ostre słowa. W dziele Vejděleka problem adopcji dzieci przez pary homoseksualne zostaje bowiem jedynie zasygnalizowany. Mężczyźni stają natomiast przed koniecznością podjęcia najważniejszej w ich życiu decyzji. Postanawiają razem zamieszkać. Zanim jednak do tego dojdzie, Ignác bez słowa pożegnania opuszcza kurort, czym niepokoi Oskara, który obawia się, że partner, przestraszony widmem stabilizacji, opuścił go na dobre. Ten jednak wraca po długiej nieobecności i przynosi ukochanemu podkładki pod szklanki, by - jak twierdzi - nie zniszczyć stołu w ich wspólnym domu. Dla Oskara to bardzo jasny komunikat: Ignác dojrzał i przyjął jego propozycję o wspólnym zamieszkaniu.

W jednej z ostatnich scen para tańczy na parkiecie, czule się obejmując i wyznając sobie miłość. Bohaterowie robią to naturalnie, bez obnoszenia się ze swoją orientacją. Zachowanie Ignáca i Oskara oznacza, że niczym nie różnią się od heteroseksualistów. Kochankowie raz się kochają, raz nienawidzą, wystawiając swój związek na niejedną próbę. Nie sposób ich nie lubić, zwłaszcza że często górują rozsądkiem i poczuciem humoru nad zachowaniem pozostałych uczestników wycieczki.

\section{Jarda i Jituš all inclusive}

Do mało rozgarniętych wycieczkowiczów należą Jarda i Jituš, którzy na wakacje do Włoch wyjeżdżają z dwójką swoich dzieci. Małżeństwo reprezentuje czeski ciemnogród - ludzi, którzy wciąż myślą o innych i świecie w zaściankowy sposób. Dlatego też Jarda i Jituš unikają jakiegokolwiek kontaktu z Oskarem i Ignácem twierdząc, że homoseksualiści mogą zarazić ich dzieci AIDS: Chyba najbardziej poruszona była Lidka (w filmie bohaterka ma na imię Jituš). Biorąc swój tępy obskurantyzm za święty instynkt macierzyński, natychmiast przywołała swe dorastajace dzieci i głośnym szeptem gorliwie do nich apelowała, żeby, na Boga, porzadnie myły ręce ${ }^{17}$. Patrzą na kochanków z jawnym obrzydzeniem i podejrzliwie, bo homoseksualizm to dla nich przede wszystkim synonim dewiacji. Trzymają się więc od pary

\footnotetext{
16 Tamże, s. 308-309.

17 Tamże, s. 170.
} 
gejów z daleka. Ich postawa względem osób z odmienną orientacją seksualną umyka jednak uwadze pozostałym członkom wycieczki. Oskar i Ignác, najprawdopodobniej przyzwyczajeni do spotykania na swojej drodze ludzi podobnego pokroju, postanowili nie zadzierać z małżeństwem i też machnęli ręką na ich niestosowne zachowanie.

Jarda i Jituš to jedyni w filmie Vejděleka bohaterowie ukazani w negatywnym świetle. Prostacki i zaściankowy stosunek do pary gejów to jednak nie jedyne cechy rozpoznawcze, którymi obdarzył ich reżyser filmu. Okazuje się, że to małżeństwo prawdziwych skąpców, którzy jako jedyni z wycieczkowiczów zrezygnowali z wyżywienia oferowanego przez biuro podróży. Do Włoch zabrali za to butle gazowe i jedzenie w słoikach. O nielegalnym przyrządzaniu przez nich posiłków dowiadujemy się, kiedy w przydzielonym im pokoju hotelowym dochodzi do wybuchu gazu. Jarda i Jituš nie są tym jednak zażenowani. W końcu pojechali do Włoch po to, by zaoszczędzić pieniądze i zabawić się jak najmniejszym kosztem. Przejazd autokarem, noclegi i dostęp do plaży w zupełności im wystarczył i nie zamierzali zapłacić za wycieczkę ani jednej dodatkowej korony. Zarówno na kartach powieści Viewegha, jak i w filmie Vejdelěka Jarda i Jituš dobitnie uosabiają prostactwo, ciasnotę umysłową i zaściankowość. Twórcy filmu nie zastosowali wobec bohaterów żadnej taryfy ulgowej, ukazując ich wady bez zbędnej życzliwości, którą obdarzyli innych wycieczkowiczów.

Owoc związku Jardy i Jituš, czyli Jakub, w niczym jednak nie przypomina swoich rodziców. Jest miłym i dobrze wychowanym chłopcem, który w przeciwieństwie do nich nie trzyma się na uboczu. Chętnie wchodzi w bliższe kontakty z pozostałymi wycieczkowiczami i jest otwarty na nowe znajomości. Zaprzyjaźnia się z Jolaną, z którą spędza czas podczas postojów autokaru w drodze do Włoch. Kobietę i chłopca połączyły bowiem fizjologiczne potrzeby. Ona cierpi na chorobę lokomocyjną i wielokrotnie wymiotuje podczas podróży. On często oddaje mocz. To o nich szepczą wycieczkowicze, kiedy po raz kolejny Karel z Karelem zarządzają postój. Nikt jednak nie protestuje. Czesi podchodzą do problemów Jolany i Jakuba ze zrozumieniem, i nawet im współczują.

\section{Vladimir jest niewinny, bo każdy Czech robi sobie dobrze}

Do grona zacofanych - Jardy i Jituš - mógłby także dołączyć Ukrainiec Oleg, bohater powieści Viewegha. W filmie został on jednak wykluczony z grona „wycieczkowiczów”. Autorzy scenariusza - Viewegh i Vejdělek 
- zastąpili emigranta neurotycznym Vladimirem, który za sprawą okularów i niepozornego wyglądu przypomina naukowca. Bohater nie jest tak kontrowersyjny i brutalny jak Oleg. Nie gwałci Jolany i nie spożywa posiłków w swoim pokoju, tak jak czynił to Ukrainiec w książce Viewegha. W rozdziale zatytułowanym Ukrainski seks Oleg traktuje ją dosłownie jak przedmiot: Na krótko nawet wyszedł z niej, ale tylko po to, by złapać ja za nogi pod kolanami i przeciagnać z ciemnego kąta, w którym dotą leżata, do jednej ze smug światła... Przenosit ja dosłownie jak mebel. Świnia ${ }^{18}$. Pisarz mógł sobie pozwolić na stworzenie tak kontrowersyjnego bohatera. Fikcja literacka rządzi się bowiem innymi prawami niż film. Poprawny politycznie Vejdělek nie mógł ukazać $\mathrm{w}$ dziele negatywnego portretu przedstawiciela mniejszości narodowej. Gdyby tak uczynił, z pewnością spotkałby się z potężną falą krytyki, a sami Czesi zarzuciliby reżyserowi brak zrozumienia dla Innych. Twórca filmu zastąpił więc kontrowersyjnego Olega Vladimirem, który z pasją onanizuje się podczas podglądania wycieczkowiczek pod wodą.

Ofiarą mężczyzny pada Jituš, która zauważa płynącego za nią mężczyznę. Wpada w histerię i z przerażeniem woła na pomoc męża. Jarda przybywa z odsieczą i na plaży odbywa się samosąd na Vladimirze zorganizowany przez pozostałych wycieczkowiczów, których stara się uspokoić Pamela. Na zawstydzonego Vladimira zwraca uwagę Jolana, która staje w jego obronie. Przekonuje oburzonych członków wycieczki, że zachowanie mężczyzny jest naturalne, bo każdy czerpie przyjemność z masturbacji czy onanizowania się, tylko nie zostaje na tym przyłapany. Wycieczkowicze przyznają jej rację, a Vladimir obiecuje poprawę.

Erotyczne fascynacje i fantazje bohatera nadają mu status obcego. W pierwszej chwili spotyka się z odrzuceniem przez wycieczkowiczów, by później zostać przez nich zaakceptowanym. Pierwszy krok w stronę jego akceptacji robi Jolana, przed którą Vladimir odsłania później tajemnice świata podwodnych podniet. Kiedy jej zaloty odrzuca piosenkarz Max, bohaterka udaje się do pokoju Vladimira. Proponuje mężczyźnie seks bez zobowiązań. Kładzie się na łóżku i wykonuje okrężne ruchy rękami i nogami, jakby pływała „żabką". Wie, że tylko w taki sposób rozpali zmysły nieśmiałego mężczyzny. W scenie tej, jak w krzywym zwierciadle, uzewnętrznia się jedna z koncepcji feministycznych mówiąca o „przyjemności patrzenia", która dzieli się na aktywną - męską, i bierną - żeńską ${ }^{19}$. To Vladimir jest tym, który patrzy i rzutuje swoje fantazje na postać „pły-

18 Tamże, s. 305.

19 Alicja Helman, Jacek Ostaszewski, Historia myśli filmowej. Podręcznik, słowo/obraz terytoria, Gdańsk 2010, s. 287. 
wającej" Jolany. Kobieta zostaje sprowadzona więc do roli obiektu jego spojrzenia - podsyca jego zainteresowanie i wywołuje reakcje pożądania, stając się seksualnym przedmiotem. Bohaterka czyni to z pełną świadomością. Czuje, że jest tyle warta, ile seks, jaki może z nią mieć Vladimir i to właśnie napędza ją do działania. Rozpaczliwie pragnie bowiem czułości i pieszczot. W tej filmowej scenie Jolana przypomina Helenę Pawlowską - bohaterkę reportażu Mariusza Szczygła. Wyzwolona seksualnie kobieta o dużym biuście i korpulentnej budowie ciała, podobnie jak Czeszka z Wycieczkowiczów, chciwie pożądała akceptacji, „spadając na mężczyzn niczym młot" ${ }^{20}$. Odbyte $\mathrm{z}$ nimi, mechaniczne stosunki, nie miały jednak nic wspólnego z miłością.

\section{Spełniona Jolana}

Zarówno w filmie, jak i w książce Jolana jest wyzwoloną, inteligentną i dowcipną kobietą, której do szczęścia brakuje tylko męża ${ }^{21}$. Wśród pasażerów autokaru widzi nawet potencjalnych kandydatów. Bohaterka najpierw proponuje „romans bez zobowiązań" Maxowi, próżnemu artyście przekonanemu o swej wyjątkowości, a na koniec idzie do łóżka z życiowym nieudacznikiem, Vladimirem.

Reżyser filmu tłumaczy jej zachowanie nadopiekuńczością rodziców, z którymi Jolana jest silnie związana. To oni zawsze zapewniali ją, że jest piękna i że zdobędzie w swoim życiu każdego mężczyznę. Kiedy więc inteligentna Jolana orientuje się, że ze swoją - tak naprawdę przeciętną urodą i nadwagą - nigdy nie zdobędzie upragnionego męża, rezygnuje z wszelkich podchodów i decyduje się wreszcie „brać, co dają". Słyszy też tykanie biologicznego zegara i za nic w świecie nie chce zostać starą panną. Dlatego decyduje się związać z niewydarzonym Vladimirem, przy którym wreszcie czuje się spełniona jako kobieta i kochanka. Poza tym Vladimir w pełni ją akceptuje i w przeciwieństwie do Maxa nie czuje do kobiety odrazy. Zanim Jolana zostaje jego kochanką, mężczyzna podaje jej reklamówkę, by mogła do niej zwymiotować w autokarze. Z roztargnienia zapomina jednak wyjąć z torby swoje okulary. W kolejnej scenie widzimy, jak je wyciąga i pogodzony z ich losem zdaje się mówić jak każdy dobry Czech: „,W końcu każdego może to kiedyś spotkać”.

20 Mariusz Szczygieł, Wytwórnia śmiechu, [w:] Zrób sobie raj, Wyd. Czarne, Wołowiec 2010, s. 203, 204.

21 Michal Viewegh, dz. cyt., 166-167. 
To m.in. dzięki takim zachowaniom Vladimira widz akceptuje wybór Jolany. W filmie jest on bardziej wiarygodny niż w powieści. Na kartach książki Jolana wiąże się bowiem z nieokrzesanym brutalem, z którym związek nabiera groteskowych cech. Uważny czytelnik dostrzeże jednak pierwiastek piękna nawet $w$ ich relacji. To specyficzne piękno, do którego przyzwyczaił nas w swoich powieściach Bohumil Hrabal. Autor Pociagów pod specjalnym nadzorem udowodnił, że wszystko, co nas spotyka może być czymś magicznym: „Cud zdarza się każdego dnia. Głupie okazuje się u niego piękne. Pokraczne jest piękne. Podłe jest piękne”222. Vejdělek uchronił Jolanę od związku z ukraińskim brutalem. Zdecydował się na bardziej realistyczne, przystające do współczesnych czasów rozwiązanie i rzucił ją w ramiona Vladimira - łagodnego faceta, który dla Jolany gotowy jest zrobić wszystko. Siłę ich związku buduje także seksualna przyjemność, którą czerpią oboje. W powieści Jolana jej nie odczuwała, a mimo to trwała przy brutalnym Olegu. W filmie kobieta jest spełniona, przystając do wizerunku zadowolonych z życia Czeszek.

Postać Jolany w filmie Vejděleka spełnia też funkcję mentora. Staje się życiową przewodniczką Jakuba. To ona uzmysławia chłopcu, że nie jest homoseksualistą, pokazując mu własne piersi, które pobudzają jego zmysły. W powieści relacja przyjaciół ma bardziej dwuznaczny charakter. Jolana czuje bowiem wyraźne podniecenie, przebywając z małym Jakubem $^{23}$. Film Vejděleka rezygnuje z tak kontrowersyjnego rozwiązania. Kobietę i chłopca łączy krystaliczna przyjaźń, bez żadnych podtekstów.

\section{Kochanek Max}

Przystojny i popularny piosenkarz Max jest pierwszym w kolejności mężczyzną, który zauroczył zakompleksioną Jolanę. Bohaterka, która imponuje mu intelektem, nie pociąga go jednak seksualnie. Jego wyobraźnią zawładnęła za to piękna, ale głupia przewodniczka Pamela. Postanawia uwieść kobietę tanimi chwytami. Pamela gra niedostępną i chce udowodnić Maxowi, że prócz pięknego ciała ma jeszcze interesującą osobowość i duszę prawdziwej artystki. Komponuje piosenki i gra na gitarze. Jej taktyka przynosi jednak efekt odwrotny do zamierzonego. Max zirytowany niedostępnością Pameli, rezygnuje bowiem z jej uwodzenia i odwraca się na pięcie niczym obrażony nastolatek. Ma nadzieję, że pocieszenie odnaj-

\footnotetext{
22 Mariusz Szczygieł, dz. cyt., s. 43.

${ }_{23}$ Michal Viewegh, dz. cyt., s. 355-357.
} 
dzie w ramionach wyzwolonej studentki Irmy, która z ochotą przyjmuje propozycję niezobowiązującego seksu z piosenkarzem. W końcu m.in. po to przyjechała do włoskiego kurortu.

Studentka stawia jednak Maxowi jeden warunek: bez prezerwatywy nie wpuści go do swojego łóżka. Seks bez zabezpieczenia z obcym facetem jest czymś niedopuszczalnym we współczesnym świecie i uświadomione Czeszki wiedzą o tym doskonale - zdaje się mówić Vejdělek. Wie o tym także przyjaciółka Irmy, Denisa, która z łatwością uwodzi ratownika czuwającego nad bezpieczeństwem wycieczkowiczów kąpiących się w morzu. Przypadek sprawia jednak, że Irma, mimo zdobycia przez Maxa prezerwatywy, zamyka przed piosenkarzem drzwi swojej sypialni. Wyraźnie niezadowolony Max odchodzi więc z kwitkiem. Wkrótce jednak szczęście się do niego uśmiecha, bo w ramiona wpada mu Pamela. Związek z nią okazuje się prawdziwą męką.

W literackiej wersji Wycieczkowiczów Max jest wziętym pisarzem i zarazem narratorem powieści. W filmie Vejděleka bohater traci obie te funkcje. Zyskuje też nową wrażliwość i nie jest już tak obcesowy w stosunku do Pameli jak w książce, kiedy niemal brutalnie przewrócit ja na twardy, mokry piasek. [...] Na twarzy Maxa rysował się głęboki, skupiony spokój. „Idziesz do kobiety? Nie zapomnij wziać bicz!"’24. W filmie jest już mniej kategoryczny. Być może dlatego ten współczesny Casanova budzi w widzach uczucie sympatii. Często jest też panem sytuacji. To on spieszy z pomocą Šarlocie i Heldze, które gubią swoje paszporty.

\section{Młodość nazywa się Irma i Denisa}

Studentki Irma i Denisa określają cel swojej podróży tuż przed wejściem do autokaru. Liczą na dobrą zabawę i płomienny romans. Bohaterki reprezentują w filmie Vejděleka, podobnie jak w powieści Viewegha ${ }^{25}$, młode, wykształcone Czeszki, które bez ograniczeń korzystają ze swych fizycznych atutów i uroków wolności na wakacjach. Uprawiają bezpieczny seks i z obrzydzeniem patrzą na podstarzałą Sarlotę oraz jej towarzyszkę Helgę, odrzucając od siebie myśl, że za kilkadziesiąt lat będą wyglądały podobnie. Studentki kierują się w życiu mottem Haliny Pawlowskiej, znanej w Czechach autorki bestselerowych powieści, która kiedyś powiedziała: Cnota - chwalcie ja dziewczyny u siebie, najlepiej w sobote wieczorem,

24 Tamże, s. 330-333.

25 Tamże, s. 11-14, 154-158, 221-224. 
kiedy samotnie siedzicie $w$ dom $u^{26}$. Pełne wigoru przyjaciółki doskonale rozumieją ironiczne przesłanie jej wypowiedzi i wcale nie zamierzają spędzać samotnych wieczorów w hotelowych pokojach. Rozpoczynają więc realizację swojego wakacyjnego planu.

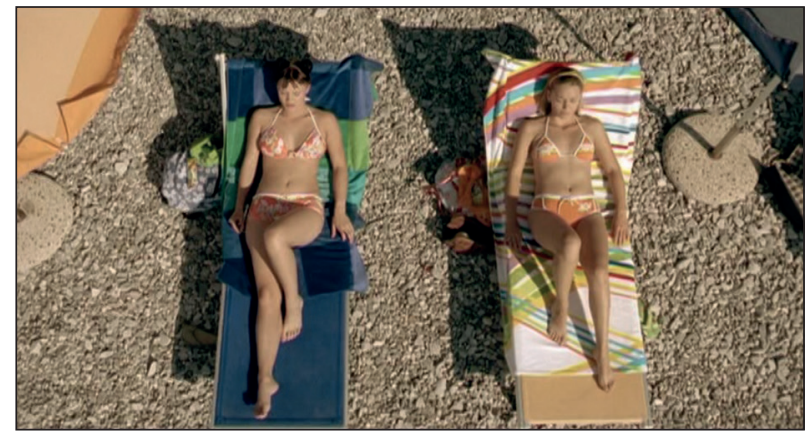

Fot. 15. Wycieczkowicze (2006, reż. Jiří Vejdělek) Bohaterki na plaży

Pierwsza na podbój wyrusza Denisa, która na oczach ratownika ostentacyjnie zdejmuje górę kostiumu kąpielowego. Daje mężczyźnie znak, że jest gotowa przeżyć z nim romantyczną przygodę. Kolejne noce spędza już w jego chatce na plaży. Denisa motywuje do działania Irmę, która miała nadzieję, że uda jej się złowić Maxa - najgorętszą partię wśród wycieczkowiczów. Stało się jednak inaczej i zdesperowana dziewczyna jest nawet gotowa pójść do łóżka z dojrzałym ojcem Jolany. Nie przeszkadza jej nawet fakt, że przyjechał on na wypoczynek z żoną. Amoralna Irma nie ma jednak nic wspólnego ze swoim literackim pierwowzorem. U Viewegha studentka posuwa się jeszcze dalej. Uwodzi żonatego posła, którego postać nie znalazła się w filmie, i całuje się z nim na oczach jego żony Zuzanny ${ }^{27}$.

Filmowa Irma zostaje wybielona. Zbieg okoliczności sprawia, że między nią a ojcem Jolany nie dochodzi bowiem do zbliżenia, a w końcu studentka ląduje w łóżku z ratownikiem Denisy. Chłopak staje się zresztą kością niezgody między przyjaciółkami. W finale filmu dziewczyny dochodzą jednak do porozumienia i rezygnują z otwartej walki o mężczyznę na rzecz przyjaźni.

\footnotetext{
26 Tamże, s. 201.

27 Tamże, s. 370-371.
} 


\section{Rodzice Jolany, czyli piwosz i jego dobra żona}

Być może ojciec Jolany nie byłby tak spragniony młodej studentki, gdyby nie zachowanie jego oziębłej żony. Łącząca ich niegdyś miłość już chyba wygasła, choć mężczyzna wciąż szuka różnych sposobów, by uszczęśliwić swoją małżonkę. Rodzice Jolany są przykładem pary z długoletnim stażem. Kłócą się i godzą, kochają się i nienawidzą. Bohaterów poznajemy w momencie kulminacyjnym kolejnego małżeńskiego kryzysu. Przestali ze sobą sypiać, a nawet rozmawiać. W oczach Jolany, jak pisze Viewegh, wciąż są jednak parą idealną. Córka dostrzega siłę łączącego ich uczucia w prozaicznych zachowaniach i gestach: przyniesionej przez ojca kawie i szeptanym na ucho słówkom: Matka Joli odpowiedziała mu z uśmiechem, ojciec tylko kiwnat głowa, ale jego twarz miała przyjacielski, niemal radosny wyraz. W Joli ta niema, banalna scena wywołała nieoczekiwanie krótkotrwałe poruszenie $^{28}$. W filmie niechęć kobiety w stosunku do męża, który niegdyś imponował jej wyglądem i sprawnością, stanowi natomiast punkt wyjścia i szybko obraca się przeciwko niej. Zaniedbany i niedoceniony mąż szuka bowiem spełnienia w ramionach młodszej. Skrywa on też przed żoną informację o tym, że kilka tygodniu temu zwolniono go z pracy. Nie wie, że kobieta już dawno odkryła jego tajemnicę i w milczeniu oczekuje na spowiedź męża.

Rodzice Jolany przezwyciężają jednak uczuciowy kryzys i odnajdują do siebie drogę. Wyrażają to w scenie, w której łączą ze sobą odseparowane, jak do tej pory, łóżka. Dają widzom nadzieję, że we współczesnym świecie małżeński związek przetrwa wszelkie problemy. Żona, jak to często w życiu bywa, przebacza mężowi udział w nocnych, hotelowych imprezach i, co najważniejsze, przymyka oko na jego uzależnienie od piwa. Używka ta staje się zresztą w filmie atrybutem ojca Jolany, typowego czeskiego piwosza, który swą głupotę zalewa właśnie „beczkami piwa” - jak stwierdziłby Vratislav Effenberger, śledzący rozwój wizerunku czeskości $\mathrm{w}$ kinie na początku XX w.

Badacz sformułował swoje tezy $\mathrm{w}$ artykule zatytułowanym Obraz człowieka w filmie czeskim, opublikowanym na łamach czasopisma „Film a doba" w 1968 r. ${ }^{29}$ Wizerunek, który opisał Effenberger, uobecnia się także w kinie czeskim XXI w. Ojca Jolany, który stracił pracę i stał się nikim

28 Tamże, s. 140.

29 Vratislav Effenberger, Obraz człowieka w filmie czeskim, tłum. Anna Car, [w:] Czeska myśl filmowa, t. 2: Reguly gry, red. Andrzej Gwóźdź, słowo/obraz terytoria, Gdańsk 2007, s. 212-231. 
w hierarchii społecznej, charakteryzują cechy bliskie bohaterom analizowanym przez Effenbergera ponad czterdzieści lat temu:

Swoista przebiegłość, która pozwala im żyć wygodnie. Ich pełna samozadowolenia familiarność i piwny prowincjonalizm stanowią idealne drogowskazy, którymi kierują się w życiu pozbawionym ambicji, i wykluczają jakąkolwiek, społeczna, polityczną czy filozoficzną refleksję nad swoim losem. Ich celem jest przetrwać możliwie najspokojniej i najwygodniej, bez jakichkolwiek zakłóceń, wyzwań czy pragnieńn ${ }^{30}$.

Ojciec Jolany nie wzbudza jednak w widzach odrazy. To w końcu poczciwiec, który stracił pracę i najchętniej schowałby się pod spódnicą małżonki. Czeka tylko na jej zgodę. Współczujemy mu. Doskonale wiemy, że mężczyzna pije, bo tylko pod wpływem alkoholu czuje się tak naprawdę szczęśliwy i... młody. Zapomina o trapiących go problemach, takich jak utrata pracy, nabierając odwagi do stawienia czoła szarej codzienności, a przy okazji podrywa młodą Irmę. Wiemy jednak, że nigdy nie odejdzie od żony.

\section{Šarlota i Helga w kolorze sepii}

Siłę uczucia do zmarłego męża uosabia nobliwa Šarlota. Bohaterka udaje się w podróż do Włoch, bo właśnie tam spędziła z nim najpiękniejsze chwile. Odżywają wspomnienia, na skutek czego Šarlota traci poczucie rzeczywistości, żyjąc na granicy jawy i snu. W jednej ze scen widzi nawet ukochanego. Rozpoznaje jego sylwetkę i jasny kapelusz, który nosił. Šarlota podąża więc za obiektem swoich westchnień. W twarzy mężczyzny nie rozpoznaje jednak męża.

Relacje starszej bohaterki z jej nieżyjącym małżonkiem tworzą w filmie Vejděleka najciekawsze wątki. Zepchnięte na margines $w$ powieści Viewegha, zostały wyeksploatowane przez reżysera. W jednej z ostatnich scen twórca filmowych Wycieczkowiczów aranżuje spotkanie Šarloty i jej męża na drewnianym molo. Bohaterka słyszy nieuchwytną dla innych muzykę i tańczy tango z wyimaginowanym partnerem. Widzimy przemianę bohaterki uciekającej w marzenia. Kolorowy film płowieje, a w barwach sepii Šarlota nie przy pomina już siebie. Widzimy młodą dwudziestokilkuletnią kobietę, która czuje się bardzo szczęśliwa w ramionach ukochanego. Jej piękny sen przerywa nagle Helga. Rozczulona widokiem przyjaciółki,

30 Tamże, s. 269. 
postanawia towarzyszyć jej w tańcu. Na tle różnych zachowań wycieczkowiczów to najpiękniejsza scena w filmie.

Relacje między koleżankami w podeszłym wieku nie zapowiadały jednak takiego finału. Młodsza Helga nie mogła bowiem zrozumieć zachowania starszej Šarloty. Uważała, że jej przyjaciółka straciła zmysły i zwariowała na stare lata ${ }^{31}$. Jej sentymentalne zachowanie zaczęło też Helgę irytować. Bohaterka ma jednak poczucie misji. Traktuje więc zdziwaczałą i nieco zagubioną Šarlotę jak małe dziecko, które wymaga ciągłej opieki. Decyduje o zawartości jej bagażu podróżnego i sposobie spędzania wolnego czasu. Brakuje jej jednak empatii. Zamiast pomóc koleżance, kiedy ta pogrąża się w rozpaczy, odkrywając, że zgubiła paszport, Helga oskarża ją publicznie o roztargnienie. W drodze powrotnej z Włoch okazuje się, że tym razem to ona zawieruszyła swój paszport i będzie potrzebowała pomocy.

Šarlota i Helga są najstarszymi reprezentantkami czeskiego społeczeństwa wśród wycieczkowiczów. Mimo wielu wad to one, wraz matką Jolany, zachowują na wakacjach resztki godności. W przeciwieństwie do małżeństwa Jardy i Jituš akceptują też parę homoseksualistów, uśmiechają się tylko swawolnie i wyrozumiale, jakby chciały powiedzieć: w życiu nic nas już nie zaskoczy.

\section{Naiwna Pamela}

Piękna pilotka wycieczki do Włoch o imieniu Pamela to prosta dziewczyna. Bohaterka patrzy na świat przez różowe okulary, kocha swoją pracę, która przynosi jej prawdziwe spełnienie. Zwraca się do podróżnych słodkim głosikiem i śpiewa im do snu kołysanki, przygrywając na gitarze.

Młoda pilotka elektryzuje też wszystkich mężczyzn, a jej długie nogi, jędrne piersi i talia osy wprawiają większość kobiet w kompleksy. Pamela wygląda z pozoru jak pusta, plastikowa lalka, która nie ma nic do zaoferowania światu poza swoją urodą. Nie grzeszy bowiem intelektem. Młoda pilotka ma jednak zasady - nigdy nie idzie do łóżka z mężczyzną, który nie traktuje jej z szacunkiem. Nie znosi prostactwa, dlatego też nie reaguje na tanie chwyty Maxa, usilnie próbującego ją uwieść.

31 Michal Viewegh, dz. cyt., s. 152-154. 
Postać Pameli została potraktowana przez Vejděleka powierzchownie. Reżyser powielił w filmie jedynie stereotypowe myślenie o blondynkach - głupiutkich i nieco infantylnych trzpiotkach. Literacki pierwowzór postaci różni się od filmowego obrazu Pameli. W książce bohaterka nie śpiewa wycieczkowiczom kołysanek, ale za to czyta im autorskie bajki ${ }^{32}$. Viewegh pogłębił też osobowość pozbawionej intelektualnego pierwiastka młodej kobiety. Dowiadujemy się na przykład, że codziennie poddaje ona swoje piękne ciało wielu upiększającym zabiegom i nie wychodzi z domu bez nałożenia na siebie kilku warstw pachnącego balsamu. Marzy o księciu z bajki, którego może spotkać w każdej chwili i chce być na ten moment jak najlepiej przygotowana ${ }^{33}$. Dbająca o siebie Pamela nie jest jednak świadoma siły, z jaką oddziałuje na mężczyzn. Nie rozumie, dlaczego się za nią oglądają i gwiżdżą, mijając ją na ulicy: Była zazwyczaj zszokowana i zniesmaczona chamskim gapieniem się i odzywkami facetów, którzy w ten sposób reagowali na jej wymyte, wymalowane, pachnace $i$ wypudrowane ciało ${ }^{34}$. Tak reagujący na jej wygląd mężczyźni w ogóle jej jednak nie interesowali.

Zarówno w filmie, jak i w powieści Pamela wzbudza sympatię i żal. Kobieta daje się złapać w sidła Maxa, planując już ich wspólną przyszłość. Nie wie jednak, że po powrocie wycieczki do Pragi uwodziciel zamierza ją porzucić. Symbolem naiwności bohaterki staje się chrześcijański krzyżyk, ukazujący się między jej ponętnymi piersiami. W laickich Czechach to widok niezwykle rzadki, dowód ludzkiej głupoty i powód do śmiechu. Okazuje się jednak, że i sama Pamela nie przywiązuje do jego religijnej symboliki żadnej wagi. W finale filmu łamie „śluby” czystości, oddając się Maxowi i wcale nie ma $z$ tego powodu wyrzutów sumienia.

\section{Zwyczajni wycieczkowicze}

Blondynka Pamela, zrezygnowana Jolana i zdominowana przez Jardę Jituš to postaci, które stoją w opozycji do wyzwolonych studentek, Denisy i Irmy, oraz zdystansowanych do życia matki Jolany, Šarloty i Helgi. Wszystkie bohaterki w Wycieczkowiczach łączy jednak jedna cecha. Są zwyczajne do szpiku kości. To kobiety, które mijamy codziennie na ulicy, pracujemy z nimi, jeździmy autobusami i spotykamy na zaku-

\footnotetext{
32 Tamże, s. 115-117.

33 Tamże, s. 18-20.

34 Tamże, s. 20.
} 
pach. Każda z nich ma własne problemy. Żyją chwilą i marzą o spełnianiu własnych pragnień w zależności od wieku. Nie ma wśród nich prawdziwych intelektualistek (bez powodzenia kreują się na nie studentki) czy bogobojnych feministek - typowych bohaterek naszych czasów. Nie taki bowiem pejzaż bohaterek chciał odmalować w swoim filmie Vejdělek, bo kto chciałby spędzić choć jeden dzień beztroskich wakacji we Włoszech z przedstawicielkami intelektualnej elity?

Czeska, urocza zwyczajność w Wycieczkowiczach charakteryzuje też mężczyzn - Jardę, Maxa i ojca Jolany oraz onanistę Vladimira, a także parę gejów Ignáca i Oskara. Mimo pewnych uszczypliwych obserwacji, które na temat Czechów poczyniono w filmie, Vejdělek potraktował swoich bohaterów z życzliwością i podszedł ze zrozumieniem do ich wszystkich wad i przywar, a oni stali się przez to bardziej ludzcy oraz dzięki temu bliżsi widzom.

Reżyser patrzy na popełnione przez nich błędy z przymrużeniem oka. Nawet kiedy wytyka im rozwiązłość i głupotę, robi to z pełną świadomością. Zna swoich rodaków i wie, że może sobie na to pozwolić. Czesi słyną bowiem dystansu do siebie i jeśli ktoś przedstawia ich w nie najlepszym świetle, z pewnością może liczyć na ich pełną aprobatę. To naród, który nie jest przewrażliwiony ani na punkcie swojej czci, ani honoru. Do szału doprowadza ich tylko jedno: „Możecie mówić o Czechach jak najgorzej - nie ruszy ich to. Najwyżej potwierdzą, że macie rację. Ale niech się dowiedzą, że benzyna podrożała, usta im się nie zamkną od przekleństw" ${ }^{\prime \prime 3}$.

\section{Seks po czesku}

Bohumil Hrabal uważał, że „fantazje seksualne wpływają na myślenie w ogóle". Twierdził też, że „lubieżność pozwala wygimnastykować sobie mózgownicę ${ }^{\prime \prime 36}$. Myśli pisarza mogłyby posłużyć za motto Wycieczkowiczów. Seks bowiem napędza ich do działania i dodaje energii. Jest także źródłem wielu zabawnych sytuacji.

Jolana i Vladimir uprawiają miłość nawet w autokarze, podczas powrotu do Pragi. Robią to jednak dyskretnie. Wtuleni w siebie, fantazjują w myślach i z słuchawkami na uszach wsłuchują się w dźwięki szumiących fal. To prezent, który Jolana przygotowała specjalnie dla Vladimira, nawiązując do jego podwodnych igraszek. Na kartach powieści Viewegha

35 Mariusz Szczygieł, dz. cyt., s. 231-234.

36 Za: tamże, s. 73. 
bohaterka decyduje się na danie upustu swojemu podnieceniu i masturbuje się pod kocem, co zauważa Denisa: Jola przełknęła ślinę $i$ szybko oddychała nosem. Wyciagnęła ręce spod koca i położyła je na oparciu siedzenia Denisy, która miała wrażenie, że czuje promieniujacy z nich żar i ten znajomy zapach ${ }^{37}$. Zaspokojone wyjeżdżają z Włoch także Irma i Denisa oraz Max, który zdobył wreszcie boską Pamelę. Narzekać nie mogą też Oskar i Ignác oraz rodzice Jolany, którzy w finale filmu połączyli hotelowe łóżka w geście małżeńskiego pojednania.

Wszyscy wycieczkowicze zachowują się swobodnie i otwarcie mówią o swoich seksualnych - naturalnych potrzebach. Wszyscy, z wyjątkiem Jardy i Jituš, są także tolerancyjni dla zachowań odmiennych od norm heteroseksualnych. W zachowaniach większości bohaterów filmu Vejděleka odbijają się bowiem liberalne poglądy zarówno Czechów, jak i Czeszek w sferze obyczajowej, z których są znani w całej Europie. Otwarcie o seksie nie tylko pisze, ale i mówi Michal Viewegh:

Seks jest naturalną częścią mojego życia, tak samo zresztą jak masturbacja, dlatego te tematy są także naturalnym elementem moich książek. Jestem przeciwny hipokryzji. [...] Kiedy spotykam się ze swoją córką czy którąś ze swoich młodszych ex-kochanek, temat seksu jest najczęściej poruszanym przez nie tematem ${ }^{38}$.

\section{Wycieczkowicze wracają do domu}

Wycieczkowicze stanowią przykład współczesnej czeskiej komedii, w której pobrzmiewają nie tylko echa tradycji zapoczątkowanej w latach 60. przez wspomnianych wcześniej Jiříego Menzla czy Miloša Formana, lecz także amerykańskich produkcji zaadresowanych do szerokiego grona odbiorców, a w szczególności do ludzi młodych ${ }^{39}$. Ich bohaterami są zwykle życiowi nieudacznicy, a seks jest jedyną rzeczą motywującą ich do działania. Wydaje się, że Vejdělek nakręcił Wycieczkowiczów ze świadomością, że to właśnie dzięki tzw. teen comedies w połączeniu ze sprawdzoną tradycją czeskiego kina jego film będzie cieszył się dużą popularnością zarówno w kraju, jak i za granicą. Epatowanie seksem, niewybredne żarty $\mathrm{w}$ połączeniu $\mathrm{z}$ prowincjonalnym poczuciem humoru Czechów w różnym wieku zawsze znajdą swoją publiczność.

\footnotetext{
Michal Viewegh, dz. cyt., s. 359.

38 Za: Mirosław Śmigielski, $d z$. cyt.

39 Frédéric Martel, Mainstream. Co podoba się wszędzie na świecie, tłum. Karolina Sikorska, Wyd. Czarna Owca, Warszawa 2011, s. 414.
} 
„Gdyby w Czechach - twierdził Mariusz Szczygieł - powstawało rocznie tylko pięć komedii i żaden film innego gatunku, mówiłoby się, że kinematografia miała udany rok. Brak wystarczającej ilości dowcipów w filmie najprawdopodobniej należy według Czechów do siedmiu grzechów głównych"40 ${ }^{\prime \prime}$ Smiejemy się zatem z bohaterami Wycieczkowiczów, bo - jak twierdził Milan Kundera - tylko „w ekstatycznym śmiechu człowiek nie wspomina ani nie planuje, lecz krzyczy do trwającej właśnie chwili świata i nie chce znać niczego poza nią" ${ }^{\prime \prime 1}$. Wycieczkowicze, w myśl słów Kundery, krzyczą carpe diem!, spędzając wakacje we włoskim kurorcie. Wychodzą bowiem z rutyny dnia codziennego. Są frywolni, wyzwoleni, a czasem nawet infantylni.

Film Vejděleka ma konstrukcję klamrową. Wycieczkowiczów otwiera scena wyjazdu bohaterów do Włoch, a finał następuje w momencie powrotu podróżnych do Pragi. Każdy z nich przeżył wyjątkową przygodę, dlatego też wszyscy wracają z poczuciem spełnienia. Jolana znalazła w końcu mężczyznę, przy którym czuje się szczęśliwa. Jej rodzice wreszcie zażegnali spór. Irma i Denisa przeżyły seksualne uniesienia. Šarlota spotkała we śnie swojego zmarłego męża. Oskar i Ignác postanowili razem zamieszkać. Jakub zrozumiał, że nie jest gejem. Jarda i Jituš nie ucierpieli finansowo z powodu wyjazdu, a Max poczuł napływającą wenę i zainspirowany piosenką Pameli, napisał nowy utwór.

Wycieczkowicze są szczęśliwi. Zdobyli nowe doświadczenia i - co najważniejsze - w końcu wracają do domu. Do Czech, które nazywają jedynym rajem na Ziemi.

${ }^{40}$ Mariusz Szczygieł, dz. cyt., s. 206-207.

41 Cyt. za: tamże, s. 208. 